\title{
Social Capital and the Sustainability of KUD Business in Donggala District, Indonesia
}

\author{
Muhtar Lutfi ${ }^{1}$, Eko Jokolelono ${ }^{1}$, Armin Muis ${ }^{1}$, Yunus Sading ${ }^{1}$ \\ ${ }^{1}$ Faculty of Economics and Business, Tadulako University, Palu, Indonesia \\ Received: September 15, 2021 \\ Received in revised: October 18, 2021 \\ Accepted: October 22, 2021
}

\begin{abstract}
This study aims to identify the social capital, co-production, and sustainability of KUD (Village Unit Cooperatives) business. It used descriptive research design using primary data obtained from KUD administrators and KUD members through the focus group discussion (FGD). It used FGD because in general KUD activities stopped after being affected by the natural disasters on September 28, 2018, and during the Covid 19 pandemic so that most of the KUD administrators and members were inactive and difficult to find. The findings of this study showed that (1) some KUD businesses have decreased the number of active KUD members, reduced income and SHU (net income) of KUD members due to the natural disasters that damage property and livelihoods of community members, especially members of KUD; (2) The active participation of KUD members has significantly decreased; (3) Only half of the number of KUDs are still running their activities; and (4) Overal, the social capital, coproduction, and sustainability variables of KUD business are low.
\end{abstract}

Keywords: Social Capital, Co-Production, Sustainability of KUD Business

\section{Introduction}

The sustainability of business has to meet certain requirements (Wiedmann et al., 2009). The sustainability of KUD business as an economic organization is highly determined by many factors, for example, (1) the ability to reach and meet the needs of members and the wider community; (2) economically feasible business scale, especially in producer cooperatives that can strengthen the cooperatives' bargaining position; (3) the level of mastery of knowledge and technology of the members, especially cooperative managers; (4) a high level of independence and competitiveness of cooperatives in the market competition; and (5) the level of loyalty of cooperatives members in developing the cooperatives.

Even though many new KUD business units have emerged in Donggala District, some old KUD business units have collapsed. The cooperatives data in Donggala District showed a significant increase in the number of cooperatives from 127 units in 2008 to 149 units in 2014 but it decreased to 132 units in 2015 (Central Statistics Agency, 2016). The decrease continues to the present. In December 2019, there were only 50 cooperatives, consisting of 11 business varieties spread over 13 sub-districts. It is interesting to deeper explore the type of KUD because the largest number reaches 8 units (16\%) and spread over 6 sub-districts. Meanwhile, the number of active cooperatives only reached 30\%. This reality indicates that the sustainability of KUD businesses in Donggala is relatively low. Why does it happen? Indeed, the efforts to develop cooperatives in this district were through (1) sectoral development programs such as agricultural cooperatives, fishing cooperatives, and village unit cooperatives (KUD); (2) government institutions, such as civil servant cooperatives and other functional cooperatives; and (3) state-owned and private companies, including employee cooperatives. As a result, the initiatives of the wider community are underdeveloped and even if they exist, they are not given their proper place resulting in low independence of the cooperatives. 
Cooperatives as member-based organizations are another form of voluntary associations that grow and develop on the initiative of a group of people to move and achieve a common goal, namely improving the welfare of its members. They join in establishing cooperatives because they are motivated by strong ownership of social capital, that is a high mutual trust between the members so that they are also willing to bind themselves to shared mutual agreements and norms. As cooperatives are not based on the strength of economic capital like corporations, their strength relies entirely on the participation of the members. In this case, the participation of cooperative members is intended as a form of willingness to responsibly carry out obligations and to use their rights to support the cooperative. Therefore, the progress of the cooperative depends on the quality of participation of the members.

Currently, the variety of life of cooperatives in Donggala District is increasingly difficult and complex. The problems are increasingly unique and uncertain with a less conducive business climate, faster and stronger business integration and collaboration, severely damaged cooperatives' infrastructure, and members' loss of the source of livelihood as a result of the natural disasters in 2018 and the COVID-19 pandemic in early 2020.

The portrait of cooperative life and the dynamic changes of the external environment as elaborated above causes the helplessness of cooperatives to recover from damages. This is due to the stop of productive activities of the community, especially cooperative members, loss of livelihoods, and non-functional productive assets as a result of natural disasters. This condition becomes the main factor affecting the decline of cooperatives activities such as difficulty to conduct meetings for the members, stop productive activities, and stopped participation of members in supporting and developing the cooperative.

Whether we realize it or not, when cooperative members have lost their communication, they will lose their spirit of togetherness and decrease their mutual trust among them. Therefore, efforts to bring back this spirit to maintain the sustainability of KUD business are heavier and more difficult. In other words, social capital ownership of cooperatives has weakened

The condiction above describes the reality of cooperatives in Donggala District. It is not surprising that most cooperatives are stopped temporarily. This needs to be underlined that in developing cooperatives, especially in the worst conditions due to natural disasters and the COVID-19 pandemic, it is not only relying on ownership of physical assets, but also combine them with non-physical assets in the form of social capital, co-production, and other elements such as creativity and innovation. It is important and has even been proven that only cooperatives that care about increasing the capacity of their non-physical assets have the opportunity to innovate and stand the changes in their external environment, and it is where the role of social capital will be tested.

Those challenges require cooperatives to have the ability to quickly and flexibly respond to every opportunity, threat, demands of the member (customer), competitors' efforts, and regulatory changes. To achieve this level of capability, it requires the support of strong social capital and co-production, a good and comprehensive understanding of the sustainability of the KUD business and its elements. The study aims to identify indicators of social capital and coproduction which play important roles in maintaining the sustainability of KUD business.

\section{Literature Review}

\section{Business Sustainability}

Business sustainability can be interpreted from two perspectives, both social and economic perspectives. First, based on the social perspective, business sustainability is quite similar to social resilience that is the ability of the community to survive and recover from environmental 
pressures, social, economic, or political upheaval. The social resilience of a community is closely related to the availability of social capital as social capital is predicted to affect the social resilience of the community. A community is considered to have social resilience if it is 1) able to effectively protect its members, including vulnerable individuals and groups from changes or social and natural upheavals; 2) able to make social investments in profitable social networks; and 3) able to develop effective mechanisms for managing conflict and violence (Hikmat, 2001).

Like cooperative members, this study tries to maintain the sustainability of KUD businesses amid the heavy pressure from the impact of natural disasters, fierce competition in the home industry, and other internal and external problems of cooperatives that are difficult to predict or control. Based on the economic perspective, there are ways to maintain, develop, and protect resources to meet the needs for business sustainability in which they are based on self and other experiences and based on economic conditions.

Business sustainability is a form of resilience that shows the ongoing process of the business. Business sustainability is important for long term business resilience. Based on Dow Jones Sustainability Indexes (DJSI), the concept of business sustainability describes a long-term business which capable of creating opportunities and managing risks as well as obtaining economic and social benefits (Devi, 2006).

Efforts to maintain the sustainability of cooperatives do not only require physical capital but also non-physical capital such as social networks that can connect cooperative managers with their members (bonding social capital); relationships with people outside the group such as workers in other related fields (bridging social capital); and relationships with people with the political or financial power to gain opportunity and mobility (linking social capital).

Based on the elaboration above, it can be concluded that economically, business sustainability is the ability to create opportunities and manage risks, gain economic and social benefits, and adaptability to changing conditions. Efforts to maintain the sustainability of cooperatives do not only require physical capital support but also non-physical capital, especially social capital and co-production.

\section{Social Capital}

Social capital is a condition that makes society or a group of people move to achieve a common goal. Social capital is created with many interconnected elements (Burt, 2001). This movement emerges because it is supported by distinctive values and norms, namely trust, mutual acceptance, tolerance, appreciation, proactive collaboration, and positive values that can lead to common goals (Djohan, 2008).

Several authors of the social capital literature such as (Adler \& Kwon, 2002; Coleman, 1990; Ostrom, 1996; Robison et al, 2002; Tsai \& Ghoshal, 1998) and results of research conducted by (R. Putnam, 1993) in Northern Italy; (R. D. Putnam, 2011) in the United States; (Fukuyama, 1995, 2000) in some countries in Asia such as China and Japan; and (Miguel et al., 2003) in Indonesia conclude that social capital plays an important role in solving problems of organization, democracy, economy, and poverty. Further, social capital at the micro-level is defined as the network of relationships that individuals have. However, at the macro level, social capital refers to a social structure that supports the effectiveness of local government through community participation in government.

The utilization of social capital is the main basis for efforts to maintain the sustainability and development of voluntary associations in supporting the socio-economic life of a community. The social capital of the community is a social energy that never runs out and is difficult to 
imitate, so mobilizing the community's social capital is an effective way of empowering all resources to maintain its sustainability.

Social capital in the management of KUD business emerges to carry out its business interactions. This social capital does not belong to individuals but belongs to all because social capital is tied up in the structure of the business interaction. Social capital means nothing without integration with other forms of capital such as economic and human capital (Moelyono, 2007). The function of social capital highly depends on the variety, extent, coverage, and intensity of the cooperation that are developed by those involved in KUD business. This definition makes social capital is believed to be a valuable productive capital like economic or human capital. Without social capital, cooperatives cannot optimally obtain material benefits and other successes.

Social capital is an important aspect in the management of cooperatives because it can solve problems related to coordination, reduce transaction costs, and facilitate the flow of information between members, and significantly contribute to the superiority of cooperatives. Besides, social capital is a glue that strengthens the relationship between members as a basis to strengthen togetherness in achieving the interests and goals of the cooperative. Thus, the utilization of economic capital will be more effective and efficient, and strengthening social capital can eliminate trade-offs that occur in cooperatives. Joining as a member of cooperatives is not only because of the same economic interests, but also the similarity in social interests which will further strengthen the relationship between members. Social capital refers to the institutions, relationships, and norms that shape the quality and quantity of KUD business.

The study found that social capital in cooperatives has a significant role. Social capital highly influenced the cooperative movement in Denmark and Poland (Chloupkova et al., 2003). Participation in a civil action in Denmark was twice that in Poland, and the level of confidence in Denmark was greater (73.9\%) than in Poland (20.1\%). It happens because, in Poland, the accumulation of social capital has been reduced by the communist regime that once ruled the country.

Social capital is created from the results of interactions and between-actions. It does not belong to individuals, but the space between people. The complementary social capital of institutions grows from below, comes from people who form social connections and networks based on the principle of "... trust, mutual reciprocity, and norm of action" (Fukuyama, 1995). Shortly, social capital can be used to maintain the sustainability of KUD business because it has sociocultural values that respect the importance of cooperation to grow and develop on its own.

\section{Roles of Co-prodution in the Development of Cooperatives}

Co-production is a process that reflects the active role of a community group in the provision of goods and service interests. This active role shows that the community participates in all activities related to economic, social, political, and cultural interests as well as other interests for the sake of their welfare as a social group. The term co-production was proposed (Ostrom, 1996) to show the potential relationships that could be exploited between "official" service providers (such as the police who are in charge of maintaining security, teachers who teach in schools, and employees of puskesmas who provide health services, etc.) and community who want a safe living environment, smart students, and healthy society.

The current co-production trend is evident in some literature with the increasing number of publications that discuss the community's involvement (Mees et al., 2018). Many studies concerning co-production focus on supply companies and analyze their contribution to corporate improvement (Etgar, 2008; Mills et al., 1983) and business strategy (Lambert \& García-Dastugue, 2006). Co-production focuses on inclusion, collaboration, integration, 
reflexivity, and usability (Polk, 2015). Co-production covers an understanding of how a service is carried out through cooperation between the government and the community. Concerning its duties and functions, a government agency provides the infrastructure for public services, while the community participates in carrying out these services in accordance with their resources and capabilities. Therefore, the terms of co-production highlight more on how service activities are considered a shared responsibility and interest. The definition of co-production refers to the implementation of specific service activities or projects that stand on their own. Therefore, community participation in co-production relates more to the notion of self-help community which has been known for a long time in the implementation of community development in Indonesia.

A previous study concluded that development carried out purely through self-help without outside assistance and intervention, has a positive impact, namely the creation of a strong sense of belonging to all citizens (Alkire et al., 2001). The existence of such a feeling has generated a strong desire to maintain all the results achieved and built with their efforts, both physical infrastructure and facilities as well as social and cultural values as the guidelines for life and social group identity.

\section{Methods}

This study used a descriptive design that provided an overview of social capital, co-production, and the sustainability of the KUD business in Donggala District. It focused on indicators of social capital, co-production, and the sustainability of the KUD business. The sample was determined with the proportion of 24 administrators of KUD based on the census (3 administrators in each KUD, consisting of the chairman; secretary; and treasurer). The use of the census method is expected to provide data and information which better reflects the real condition of the field. Meanwhile, the primary source representing KUD members was purposively selected with a total of 24 KUD members (3 members in each KUD).

Data and information collected from primary sources include the indicators of (1) performance; (2) business sustainability; (3) social capital; and (4) co-production of KUD business. Data collection was carried out in some stages. First, it was started with discussions with the Cooperative Field Extension officers (PPLK). They are contract workers under the control of the Donggala District Cooperative Office. It aims to obtain preliminary information about KUD activities in 6 sub-districts and to design research instruments in accordance with the research needs, namely obtaining information about performance, business sustainability, and social capital of KUD business; Second, to determine an effective data collection technique in accordance with the presence of the population and samples in the field, it used a limited focus group discussion (FGD) or semi-FGD method to collect data from KUD administrators and members. It used semi-FGD techniques because in general KUD activities have stopped after being affected by the natural disaster on 28 September 2018 and during the COVID-19 pandemic so that most KUD administrators and members are inactive and difficult to find because most of them move out of the village to make livings.

The FGD was limited for each theme (research variables) focusing on the indicators used and the results were narrowed down by using the semantic differential scale measurement technique, which is a tool to measure the attitudes or opinions of FGD participants on a series of bipolar characteristics such as high-low, strong-weak, and good and bad towards research variables that are arranged on a continuous line ranging from very positive to very negative responses or vice versa. Besides, documentation techniques were also used to trace data sourced from official documents from the Donggala District Cooperative Office and BPS Donggala District as well as the Annual Member Meeting (RAT) document in each KUD. 
Then, the obtained data or information was analyzed using descriptive analysis techniques to (1) describe the condition and performance of the KUD; (2) analyze the aspect of sustainability of KUD business; and (3) analyze the aspect of social capital and coproduction related to the sustainability of the KUD business.

\section{Results and Discussion}

\section{General Overview of KUD}

KUD is a multi-business cooperative in which the members are villagers and located in a rural area whose working area covers one sub-district. The KUD establishment is an incorporation of several small agricultural cooperatives in rural areas. The presence of the KUD is expected to help farmers through the provision of (1) capital; (2) agricultural equipment; (3) fertilizer, seeds, and planting needs at low prices; and (4) counseling and guidance of proper planting system for maximum results.

Based on data from the Donggala District Cooperative Office (2019), there were 8 KUD units. After conducting a limited FGD with selected informants, it was revealed that this district only has 5 active KUD units with a variety and low levels of business capacity, namely (1) KUD Budi Mukti in Budi Mukti Village, Dampelas Sub-district; (2) KUD Bina Mukti in Malonas Village, Dampelas Sub-district; (3) KUD Sukamaju in Batusuya Village, Sindue Sub-district, (4) KUD Sekar Tani in Tanampulu Village, Banawa Selatan Sub-district, and (5) KUD Teladan in Wani I Village, Tanantovea Sub-district. All of KUD units reached their top performance in the 1990s when the government highly supported them through the distribution of subsidized fertilizers, food credit, agricultural business credit, and others.

At the beginning of the New Order Regime, the issue of government regulations and policies which did not benefits the KUD, almost all of the supports was eliminated. Thus, KUD experienced a decline both in terms of business and institutions. It indicates that the existence of KUD in Donggala District still depends on government assistance with a low level of business sustainability.

Based on the results of limited FGDs with informants (administrators and members of KUD) in Donggala, the latest condition of KUD development is presented in Table 1. Table 1 contains information about membership, operational activities, capital, and SHU from KUD business as well as activities of KUD service center. Based on Table 1, the active participation of KUD members after the natural disasters (earthquake, liquefaction, and tsunami) in September 2018 and the COVID-19 pandemic significantly decreased. Most of the KUD members no longer carry out their obligations and use their rights as members of the KUD. Natural disasters destroy property and sources of livelihood of the members. Hence, they prioritize the basic needs of households. Members' obligations to pay loans to the KUD were interrupted and some of the KUD's businesses stopped. As a consequence, it decreases the income and SHU of the members.

Table 1. The Latest Condition of KUD in Donggala District

\begin{tabular}{|c|c|c|c|c|c|c|c|c|}
\hline \multirow{2}{*}{$\begin{array}{l}\text { Name of } \\
\text { KUD }\end{array}$} & \multirow{2}{*}{ Location } & \multirow{2}{*}{$\begin{array}{c}\text { Year of } \\
\text { establish } \\
\text { ment }\end{array}$} & \multicolumn{2}{|c|}{ Number of member } & \multirow{2}{*}{$\begin{array}{c}\text { Active } \\
\text { business }\end{array}$} & \multirow{2}{*}{$\begin{array}{c}\text { Capital } \\
\text { (IDR } \\
\text { million) }\end{array}$} & \multirow{2}{*}{$\begin{array}{c}\text { SHU } \\
\text { (IDR } \\
\text { million) }\end{array}$} & \multirow{2}{*}{ Notes } \\
\hline & & & Registered & Active & & & & \\
\hline $\begin{array}{l}\text { 1.Bina } \\
\text { Mukti }\end{array}$ & $\begin{array}{c}\text { Malonas Village } \\
\text { Dampelas Sub- } \\
\text { district }\end{array}$ & $11-1-1993$ & $\underline{232}$ & 260 & RMU, & $1.117,898$ & 4,415 & $\begin{array}{c}\text { Latest RAT } \\
28-8-2019 \\
\text { Office functions }\end{array}$ \\
\hline
\end{tabular}




\begin{tabular}{|c|c|c|c|c|c|c|c|c|}
\hline $\begin{array}{l}\text { 2.Budi } \\
\text { Mukti }\end{array}$ & $\begin{array}{c}\text { Budi Mukti } \\
\text { Village } \\
\text { Dampelas Sub- } \\
\text { district }\end{array}$ & $\begin{array}{l}23-5- \\
1988 .\end{array}$ & 480 & 60 & RMU & 910,571 & 4,465 & $\begin{array}{l}\text { Latest RAT } \\
28-4-2019 \\
\text { Office not } \\
\text { function }\end{array}$ \\
\hline $\begin{array}{l}\text { 3.Maputi } \\
\text { Jaya }\end{array}$ & $\begin{array}{l}\text { Sabang Village } \\
\text { Dampelas Sub- } \\
\text { district }\end{array}$ & $\begin{array}{l}31-1- \\
1979\end{array}$ & 190 & na & stop & 142,709 & Nihil & $\begin{array}{c}\text { Latest RAT } \\
\text { 10-9-2019 } \\
\text { Office closed }\end{array}$ \\
\hline 4.Remaja & $\begin{array}{c}\text { Tompe Village } \\
\text { Sirenja Sub- } \\
\text { district }\end{array}$ & $\begin{array}{l}31-1- \\
1979\end{array}$ & 1.273 & 60 & $\begin{array}{l}\text { Cloves } \\
\text { farm }\end{array}$ & 702,529 & nihil & $\begin{array}{c}\text { Latest RAT } \\
15 \text { Mei } 2018 \\
\text { Office has severe } \\
\text { damages } \\
\end{array}$ \\
\hline $\begin{array}{r}\text { 5.Suka } \\
\text { Maju }\end{array}$ & $\begin{array}{c}\text { Batusuya } \\
\text { Village } \\
\text { Sindue Sub- } \\
\text { district }\end{array}$ & $1-6-1992$ & 58 & 36 & $\begin{array}{l}\text { Saving } \\
\text { and loan }\end{array}$ & 104,558 & 3,732 & $\begin{array}{l}\text { Latest RAT } \\
17-2-2019 \\
\text { Office closed }\end{array}$ \\
\hline $\begin{array}{r}\text { 6.Sinar } \\
\text { Tani }\end{array}$ & $\begin{array}{c}\text { Tanampulu } \\
\text { Village } \\
\text { Banawa Selatan } \\
\text { Sub-district }\end{array}$ & $\begin{array}{c}29-8- \\
1991\end{array}$ & 24 & na & $\begin{array}{l}\text { RMU; } \\
\text { electricit } \\
\quad \mathrm{y}\end{array}$ & 464,736 & 5,183 & $\begin{array}{c}\text { Latest RAT } \\
\text { 18-3-2018; } \\
\text { Office has } \\
\text { moderate } \\
\text { damages; }\end{array}$ \\
\hline 7.Pesat & $\begin{array}{c}\text { Limboro } \\
\text { Village } \\
\text { Banawa Tengah } \\
\text { Sub-district } \\
\end{array}$ & $\begin{array}{l}22-4- \\
1988\end{array}$ & 1.500 & na & stop & $1.738,924$ & nihil & $\begin{array}{l}\text { Latest RAT } \\
\text { 18-3-2018; } \\
\text { Office not } \\
\text { function; }\end{array}$ \\
\hline 8.Teladan & $\begin{array}{c}\text { Desa Wani I } \\
\text { Kec.Tanantovea }\end{array}$ & $\begin{array}{c}23-3- \\
1986\end{array}$ & 1.739 & 20 & $\begin{array}{l}\text { Local } \\
\text { market }\end{array}$ & $3.012,272$ & Nihil & $\begin{array}{c}\text { Latest RAT } \\
\text { 12-9-2019; } \\
\text { Office has } \\
\text { moderate } \\
\text { damages }\end{array}$ \\
\hline
\end{tabular}

Source: Primary Data 2020 (re-processed)

\section{Performance of KUD}

Performance of KUD is a measure to assess the condition of the KUD based on developments and changes in internal and external factors. The internal factors cover operational aspects of the KUD, whose changes can be controlled by the management or the administrators of the KUD. Meanwhile, the external factors relate to all aspects whose changes are beyond the control of the administrators. In this study, the assessment of the performance of KUD is based on the administrators' perception of several performance indicators as presented in Table 2.

Table 2. Result of Limited FGD on Performance of KUD in Donggala District

\begin{tabular}{|c|c|c|c|c|c|c|c|c|c|c|}
\hline \multirow{2}{*}{\multicolumn{2}{|c|}{$\begin{array}{c}\text { Performance } \\
\text { indicators of KUD }\end{array}$}} & \multicolumn{8}{|c|}{ Reponses of FGD Participants } & \multirow[b]{2}{*}{$\begin{array}{c}\text { Average } \\
\text { score }\end{array}$} \\
\hline & & $\begin{array}{l}\text { Bina } \\
\text { Mukti }\end{array}$ & $\begin{array}{l}\text { Budi } \\
\text { Mukti }\end{array}$ & $\begin{array}{l}\text { Maputi } \\
\text { Jaya }\end{array}$ & Remaja & $\begin{array}{l}\text { Suka } \\
\text { Maju }\end{array}$ & $\begin{array}{l}\text { Sinar } \\
\text { Tani }\end{array}$ & Pesat & Teladan & \\
\hline 1 & Finance of KUD & 2 & 2 & 1 & 1 & 1 & 1 & 1 & 2 & 1.38 \\
\hline 2 & Internal business of & 2 & 1 & 1 & 1 & 1 & 2 & 1 & 1 & 1.25 \\
\hline 3 & $\begin{array}{l}\text { Learning and } \\
\text { growth of KUD }\end{array}$ & 2 & 2 & 1 & 1 & 2 & 1 & 1 & 1 & 1.38 \\
\hline 4 & $\begin{array}{l}\text { Perception of } \\
\text { members of KUD }\end{array}$ & 1 & 1 & 1 & 1 & 2 & 1 & 1 & 1 & 1.13 \\
\hline
\end{tabular}

Copyright ( $)$ 2021, Journal of Asian Multicultural Research for Economy and Management Study, Under the license CC BY-SA 4.0 


\begin{tabular}{|c|c|c|c|c|c|c|c|c|c|}
\hline Average score & 1.75 & 1.50 & 1.00 & 1.00 & 1.50 & 1.25 & 1.00 & 1.25 & $\mathbf{1 . 2 8}$ \\
\hline Assessment category & Moderate & Low & Low & Low & Low & Low & Low & Low & \\
\hline
\end{tabular}

Source: Primary Data (re-processed)

The informants' assessment of the performance indicators showed a relatively low average score for each indicator with average scores of 1.28 ranging from 1.13 to 1.38. Then, the assessment category showed different performance of each KUDs from a low to medium category. The KUDs with moderate performance were KUD Bina Mukti, while the other KUDs including KUD Maputi Jaya; KUD Remaja; KUD Pesat; KUD Telatan, KUD Suka Maju; KUD Sekartani; and KUD Budi Mukti showed a low-performance category. It was due to several reasons such as the absence of service after the office closure. The closure was caused by natural disasters that severely damages the office building so that the KUD business was completely stopped so resulting in a significant decrease of active members and SHU.

The assessment using the same indicators showed some KUD with moderate performance including KUD Bina Mukti; KUD Budi Mukti; KUD Suka Maju; KUD Sinar Tani, and KUD Teladan. Besides those indicators, KUDs with moderate performance still run their business, open its office, provide services to members, and generate SHU. Meanwhile, KUDs with high performance are characterized by those indicators and (1) normal and even increase business operation; (2) increase number of active members; and (3) increase amount of SHU. Based on these indicators, this study did not find any KUD with high performance.

\section{Sustainability of KUD Business}

KUD's going concern is closely related to good governance regarding developments and changes in internal and external factors. The internal factors relate to all aspects that can be controlled by the KUD management or administrators, while external factors relate to aspects whose changes are beyond the control of the KUD administrators. Therefore, KUD administrators have to always be proactive in adapting to any changes.

The sustainability of the KUD business viewed from the economic perspective includes ways of surviving, developing, and protecting resources to meet their needs and sustainability. This method comes from their own experience or other organizations based on economic conditions. Therefore, the sustainability of the KUD business can be seen from the business resilience such as financial capability, business stability, networking strength, and market confidence. In the long term, the sustainability of the business will highly determine the resilience of the KUD business. KUD business resilience is considered sustainable when it can create opportunities, manage risks, and gain economic and social benefits in a long term. To be successful in the long term, the key is to adapt to changing environmental conditions. In this study, the assessment of the sustainability of the KUD was based on the perceptions of the KUD administrators, supervisors, and members through FGDs with several themes or indicators of the sustainability of KUD business in Donggala District as presented

Table 3. Results of Limited FGD concerning the Sustainability of KUD Business

\begin{tabular}{|c|c|c|c|c|c|c|c|c|c|}
\hline \multirow{2}{*}{$\begin{array}{c}\text { Sustainability } \\
\text { indicators of KUD } \\
\text { Business }\end{array}$} & \multicolumn{8}{|c|}{ Responses of FGD Participants } & \multirow[b]{2}{*}{$\begin{array}{l}\text { Average } \\
\text { Score }\end{array}$} \\
\hline & $\begin{array}{l}\text { Bina } \\
\text { Mukti }\end{array}$ & $\begin{array}{l}\text { Budi } \\
\text { Mukti }\end{array}$ & $\begin{array}{c}\text { Maputi } \\
\text { Jaya }\end{array}$ & Remaja & $\begin{array}{l}\text { Suka } \\
\text { Maju }\end{array}$ & $\begin{array}{r}\text { Sinar } \\
\text { Tani }\end{array}$ & Pesat & Teladan & \\
\hline $1 \mid \begin{array}{l}\text { Membership } \\
\text { fee for } \\
\text { sustainability } \\
\text { of the capital }\end{array}$ & 2 & 2 & 1 & 1 & 2 & 1 & 1 & 1 & 1.38 \\
\hline $2 \mid \begin{array}{l}\text { Strategic } \\
\text { partnership in }\end{array}$ & 2 & 1 & 1 & 1 & 1 & 2 & 1 & 2 & 1.38 \\
\hline
\end{tabular}

Copyright $@$ ( 2021, Journal of Asian Multicultural Research for Economy and Management Study, Under the license CC BY-SA 4.0 


\begin{tabular}{|c|c|c|c|c|c|c|c|c|c|c|}
\hline & $\begin{array}{l}\text { business } \\
\text { financing }\end{array}$ & & & & & & & & & \\
\hline 3 & $\begin{array}{l}\text { Involvement of } \\
\text { members in } \\
\text { business }\end{array}$ & 2 & 2 & 1 & 2 & 1 & 1 & 1 & 1 & 1.38 \\
\hline 4 & $\begin{array}{l}\text { Involvement of } \\
\text { professionals } \\
\text { in business } \\
\text { management } \\
\end{array}$ & 1 & 1 & 1 & 1 & 1 & 1 & 1 & 1 & 1.00 \\
\hline 5 & $\begin{array}{l}\text { Quality of } \\
\text { KUD service } \\
\text { process }\end{array}$ & 1 & 1 & 1 & 1 & 1 & 1 & 1 & 1 & 1.00 \\
\hline 6 & $\begin{array}{l}\text { Quality of } \\
\text { KUD service } \\
\text { output }\end{array}$ & 1 & 1 & 1 & 1 & 1 & 1 & 1 & 1 & 1.00 \\
\hline 7 & $\begin{array}{l}\text { KUD access to } \\
\text { the market }\end{array}$ & 3 & 2 & 1 & 1 & 1 & 1 & 1 & 1 & 1.38 \\
\hline & Average Score & 1.71 & 1.43 & 1.00 & 1.14 & 1.14 & 1.14 & 1.00 & 1.14 & 1.21 \\
\hline & $\begin{array}{c}\text { Assessment } \\
\text { Category }\end{array}$ & Moderate & Low & Low & Low & Low & Low & Low & Low & \\
\hline
\end{tabular}

Source: Primary Data (re-processed)

In general, the overall assessment of the sustainability of KUD business indicators is relatively low, ranging from 1.00 to 1.38 with average scores of 1.21 . Moreover, the category of the assessment showed different levels of sustainability with low to moderate assessment categories. It was only one KUD unit that has a "Medium" level of business sustainability, namely KUD Bina Mukti which is located in Malonas Village, Dampelas Sub-district. On the other hand, all other KUDs showed a "Low" level of business sustainability. This is due to some reasons such as (1) low capital capacity, (2) low business stability, (3) weak or limited networks, and (4) weak market trust in KUD.

\section{Social Capital of KUD}

The role of social capital in maintaining the sustainability of KUD business is often neglected. It is because the sustainability of the KUD business is understood only as of the success of the KUD in optimally utilizing and managing financial, human, and physical capitals in the long term. This understanding is not completely wrong but it only views and places these capitals as an input indicator to produce KUD products or services and ignores the role of social capital as an input that plays an economic role in improving the performance of KUD.

The important role of social capital in economic and business activities has been highlighted by experts (Coleman, 1988; Moelyono, 2010), but in business practice in KUD, social capital is often neglected, especially in terms of local institutional, local wisdom, norms, and networks. In another case, the World Bank highly considers the role of social capital, especially in developing countries, in the implementation of poverty alleviation programs (World Bank, 1998). The importance of social capital is based on the assumption of (a) social capital related to the economy, social, and politics as well as social relations affecting the market and the state and vice versa in which the market and the state will also shape social capital in society; (b) a stable relationship between factors can promote the effectiveness and efficiency of both collective and individual behavior; (c) social capital in a society can be strengthened but requires the support of certain resources, and (d) good social and institutional relations require the support of community members. 
Social capital as an important element in the KUD business has to be seen in the process aspect, starting from the selection and procurement of inputs; coordination in mobilizing, smoothing, and speeding up the production process (including services); and marketing and distribution of output to customers (society). In these processes, the role and benefits of social capital can be identified, especially the impact of efficiency and effectiveness on all KUD business lines, ease in coordinating and mobilizing all KUD resources, and cost savings. In this study, the assessment of the social capital of KUD is based on the perceptions of KUD administrators, supervisors, and members through limited FGDs with several themes or indicators of KUD social capital as presented in Table 4.

In general, the overall assessment of KUD social capital indicators is relatively low with an average score of 1.43 or ranging from 1.00 to 1.75 . Meanwhile, the category of the assessment showed from low to moderate categories. There are 4 KUDs with a "Moderate" level of social capital, namely KUD Bina Mukti, KUD Budi Mukti, KUD Sinar Tani, and KUD Teladan. Meanwhile, the other KUDs have a low level of social capital. This low level can be seen in indicators of networks and compliance of KUD members and administrators with norms and rules to be applied in the internal environment of the KUD such as low willingness to pay the membership fee, the involvement of members in KUD business activities, and concerns on the sustainability of the business.

Table 4. Results of Limited FGD on Social Capital of KUD Business in Donggala District

\begin{tabular}{|c|c|c|c|c|c|c|c|c|c|c|}
\hline \multirow{2}{*}{\multicolumn{2}{|c|}{$\begin{array}{l}\text { Social Capital } \\
\text { indicators of } \\
\text { KUD Business }\end{array}$}} & \multicolumn{8}{|c|}{$\begin{array}{c}\text { Responses of FGD Participants } \\
\text { (Administrators, Supervisors, and Members of KUD) }\end{array}$} & \multirow{2}{*}{$\begin{array}{l}\text { Average } \\
\text { scores }\end{array}$} \\
\hline & & $\begin{array}{c}\text { Bina } \\
\text { Mukti }\end{array}$ & $\begin{array}{c}\text { Budi } \\
\text { Mukti }\end{array}$ & $\begin{array}{c}\text { Maputi } \\
\text { Jaya }\end{array}$ & Remaja & \begin{tabular}{l|} 
Suka \\
Maju
\end{tabular} & $\begin{array}{l}\text { Sinar } \\
\text { Tani }\end{array}$ & Pesat & Teladan & \\
\hline 1 & $\begin{array}{l}\text { Commitment to } \\
\text { performance } \\
\text { achievement }\end{array}$ & 3 & 2 & 1 & 1 & 1 & 2 & 1 & 2 & 1.63 \\
\hline 2 & $\begin{array}{l}\text { Responsibility } \\
\text { for service }\end{array}$ & 3 & 2 & 1 & 1 & 2 & 2 & 1 & 2 & 1.75 \\
\hline 3 & \begin{tabular}{|l|} 
Institutional \\
roles and \\
functions
\end{tabular} & 2 & 2 & 1 & 1 & 2 & 1 & 1 & 2 & 1.50 \\
\hline 4 & $\begin{array}{l}\text { Willingness to } \\
\text { pay } \\
\text { membership } \\
\text { fee }\end{array}$ & 2 & 1 & 1 & 1 & 2 & 2 & 1 & 1 & 1.38 \\
\hline 5 & $\begin{array}{l}\text { Operational } \\
\text { involvement }\end{array}$ & 1 & 1 & 1 & 1 & 1 & 2 & 1 & 1 & 1.13 \\
\hline 6 & $\begin{array}{l}\text { Concern for } \\
\text { business } \\
\text { sustainability }\end{array}$ & 2 & 1 & 1 & 1 & 1 & 1 & 1 & 2 & 1.25 \\
\hline 7 & \begin{tabular}{|l|} 
Wide \\
cooperation \\
networks
\end{tabular} & 2 & 2 & 1 & 1 & 1 & 2 & 1 & 2 & 1.50 \\
\hline 8 & $\begin{array}{l}\text { Quality of } \\
\text { cooperation } \\
\text { networks }\end{array}$ & 3 & 2 & 1 & 1 & 1 & 2 & 1 & 1 & 1.50 \\
\hline 9 & $\begin{array}{l}\text { Varied } \\
\text { cooperation } \\
\text { networks } \\
\end{array}$ & 2 & 2 & 1 & 1 & 1 & 1 & 1 & 1 & 1.25 \\
\hline & Average Score & 2.22 & 1.67 & 1.00 & 1.00 & 1.33 & 1.67 & 1.00 & 1.56 & 1.43 \\
\hline
\end{tabular}




\begin{tabular}{|l|c|c|c|c|c|c|c|c|c|c|}
\hline & $\begin{array}{c}\text { Assessment } \\
\text { Category }\end{array}$ & Moderate & Moderate & Low & Low & Low & Moderate & Low & Moderate & \\
\hline
\end{tabular}

Source: Primary Data (re-processed)

The low social capital of the KUD can be traced from the low intensity of meeting activities between KUD administrators and supervisors and the lack of KUD implementation of the RAT. In turn, they weaken the coordination function so that operational activities run slowly, and other functions within the KUD stop. Through meeting activities, higher quality communication will be built between members, administrators, and members and administrators to smoothen the flow of information and foster a sense of mutual trust between them.

Smooth flow of information through meeting activities organized by the KUD will be distributed more evenly to all members and administrators of the KUD. It can encourage the growing enthusiasm and even a culture of sharing knowledge within the KUD environment so that the KUD life becomes more dynamic and lively, and even to grow KUD culture through improving governance, production systems, marketing, and services.

The existence of social capital is substantive towards other types of capital in KUD. It is realized that social capital only is not enough for KUD to run its business, but it should be supported by quality human capital, sufficient financial capital, and sufficient physical capital. Human capital can be in the form of ownership of business knowledge, organization, communication, and mastery of digital technology. Meanwhile, financial capital can be in the form of own capital reserves that come from internal KUD in sufficient amount and potential sources of external financing as well as the capability of KUD administrators to manage these sources of financing. Meanwhile, physical capital can be in the form of facilities and infrastructure for offices as the center of KUD activities and services, production and transportation infrastructure, and others.

Financial capital helps KUD administrators to further develop their business. Furthermore, social capital also plays an important role as a bridge between KUD stakeholder groups and to the market (KUD products and services) for one part of human capital in addition to other capitals such as competence, motivation, attitudes, and culture/work ethic. Among the available types of social capital, factors of trust, networks, and norms have an important role in developing business, in connection with the interactions that exist between existing business actors, business actors and suppliers of raw materials, and between actors and buyers. Besides working capital, this business also requires financial and physical capital.

\section{Co-production}

In KUD, co-production is a process that reflects the active role of KUD members in realizing their loyalty to the common interest and the achievement of KUD goals. This loyalty can be in the form of any initiative and strengthens the achievement of KUD goals, that is the common welfare. This active role shows that KUD members are not only being served but participate in all activities related to the interests and the achievement of KUD goals for the sake of mutual welfare as members of the KUD.

The presence of coproduction is a reflection of the relationship between the KUD and its members for the sustainability of KUD business to provide excellent service to all its members and the surrounding community. Concretely, co-production is a form of productive activities carried out through cooperation between KUD administrators and members. In accordance with its duties and functions, KUD provides services to its members and KUD members actively participate in carrying out productive activities based on their resources and capabilities to support the achievement of KUD goals. 
The implementation of the productive activities is independent so that the active participation of KUD members in co-production is identic with self-help, valuable creative and productive potential of KUD members who have been neglected or not yet utilized. The assessment of coproduction in this study is based on the perceptions of the administrators, supervisors, and members of the KUD through limited FGDs on several co-production themes or indicators as presented in Table 5.

Table 5. Results of Limited FGD on Co-Production of KUD Business

\begin{tabular}{|c|c|c|c|c|c|c|c|c|c|c|}
\hline \multirow{2}{*}{\multicolumn{2}{|c|}{\begin{tabular}{|c|} 
Co-production \\
Indicators of KUD \\
Business \\
\end{tabular}}} & \multicolumn{8}{|c|}{ Responses of FGD Participants } & \multirow{3}{*}{$\begin{array}{c}\begin{array}{c}\text { Average } \\
\text { Score }\end{array} \\
1.25\end{array}$} \\
\hline & & \multirow{2}{*}{$\begin{array}{c}\text { Bina } \\
\text { Mukti } \\
2 \\
\end{array}$} & \multirow{2}{*}{$\begin{array}{c}\text { Budi } \\
\text { Mukti } \\
2\end{array}$} & \multirow{2}{*}{$\begin{array}{c}\text { Maputi } \\
\text { Jaya } \\
1\end{array}$} & \multirow{2}{*}{\begin{tabular}{|c|} 
Remaja \\
1 \\
\end{tabular}} & \multirow{2}{*}{$\begin{array}{c}\begin{array}{c}\text { Suka } \\
\text { Maju }\end{array} \\
1\end{array}$} & \multirow{2}{*}{$\begin{array}{c}\text { Sinar } \\
\text { Tani } \\
1\end{array}$} & \multirow{2}{*}{$\frac{\text { Pesat }}{1}$} & \multirow{2}{*}{$\begin{array}{c}\text { Teladan } \\
1\end{array}$} & \\
\hline 1 & $\begin{array}{l}\text { Acceptance and } \\
\text { caring }\end{array}$ & & & & & & & & & \\
\hline 2 & Local values & 1 & 2 & 1 & 1 & 2 & 1 & 1 & 2 & 1.38 \\
\hline 3 & Communication & 2 & 1 & 1 & 1 & 1 & 1 & 1 & 1 & 1.13 \\
\hline 4 & Partnership & 2 & 2 & 1 & 1 & 1 & 1 & 1 & 1 & 1.25 \\
\hline \multirow[t]{3}{*}{51} & Initiative & 2 & 1 & 1 & 1 & 1 & 2 & 1 & 1 & 1.25 \\
\hline & Average Score & 1.80 & 1.60 & 1.00 & 1.00 & 1.20 & 1.20 & 1.00 & 1.00 & 1.25 \\
\hline & $\begin{array}{c}\text { Assessment } \\
\text { Category }\end{array}$ & Moderate & Moderate & Low & Low & Low & Low & Low & Low & \\
\hline
\end{tabular}

Source: Primary Data (re-processed)

The overall assessment of coproduction indicators is relatively low, with a mean score of 1.38 and ranging from 1.13 to 1.38 . It showed different levels of co-production with low to moderate assessment categories. There were 2 KUDs that have a "moderate" level of co-production, namely KUD Bina Mukti and KUD Budi Mukti. Meanwhile, the other KUDs have a "low" level of co-production namely, KUD Sinar Tani, KUD Remaja, KUD Sukamaju, KUD Pesat, KUD Sinar Tani, and KUD Teladan.

Based on Table 5, the aspect of co-production is still low in terms of the ability of the KUD to adapt to local values, the quality of communication, and the extent and variety of KUD partnerships.

\section{Conclusion}

Based on the discussion of the results of the study, the author formulated the following conclusion is the natural disasters damaged property and sources of livelihood for community members, especially members of the KUD disrupt the members' obligation to pay loans to the KUD, and stop some KUD businesses. The logical consequence of the business disruption and decreased number of active KUD members have reduced the income and SHU of the KUD members. Active participation of KUD members after the natural disasters (earthquake, liquefaction, and tsunami) in September 2018 and the COVID-19 pandemic significantly decreased. Most of the KUD members no longer carry out their obligations and rights as members of the KUD. Only 4 out of 8 registered KUD units operate with a decreasing scale of business. The performance of KUD in Donggala District based on the results of limited FGD on several indicators showed a low category. It relates all events formulated in the conclusion points 1 to 3 . The sustainability of the KUD business based on the results of limited FGD on indicators of the sustainability of the KUD business showed a low category. The social capital of KUD business based on the results of limited FGD on indicators of social capital showed a low category. Coproduction also showed a low category.

Based on the conclusion above, to maintain social capital, co-production, and business sustainability, cooperatives are required to: Build awareness of the importance of collective

Copyright $\odot$ 2021, Journal of Asian Multicultural Research for Economy and Management Study, 
action to pay membership fees so that KUD can re-operate. Support KUD to re-operate to make the members get the benefits of the KUD. Improve KUD performance by mobilizing and utilizing all potential resources of KUD. Maintain the sustainability of KUD business through the involvement of professionals and strengthening strategic partnerships. Increase the social capital of KUD to maintain the sustainability of KUD businesses through expansion, diversity, and cooperation. Increase co-production to maintain the sustainability of the KUD business through initiative, communication, and concern, as well as considering local values.

\section{References}

Adler, P. S., \& Kwon, S.-W. (2002). Social capital: Prospects for a new concept. Academy of Management Review, 27(1), 17-40.

Alkire, S., Bebbington, A., Esmail, T., Ostrom, E., Polski, M., Ryan, A., ... Dongier., P. (2001). Community-driven development. In PRSP Source Book. Washington, D.C: World Bank.

Badan Pusat Statistik. (2016). Perkembangan Koperasi di Kabupaten Donggala.

Burt, R. S. (2001). Closure as social capital. Social Capital: Theory and Research, 31-55.

Chloupkova, J., Svendsen, G. L. H., \& Svendsen, G. T. (2003). Building and destroying social capital: The case of cooperative movements in Denmark and Poland. Agriculture and Human Values, 20(3), 241-252. https://doi.org/10.1023/A:1026141807305

Coleman, J. S. (1988). Social Capital in the Creation of Human Capital. American Journal of Sociology, 94, S95-S120. https://doi.org/10.1086/228943

Coleman, J. S. (1990). Foundations of Social Theory. Harvard University Press.

Devi, L. R. (2006). Ikatan Solidaritas, Keberdayaan dan Ketahanan Usaha Kelompok Etnis Pedagang Tekstil Pasar Klewer Surakarta. Universitas Negeri Semarang, Semarang.

Djohan, R. (2008). Lead to Getherness. Jakarta: Fund Asia Education.

Etgar, M. (2008). A descriptive model of the consumer co-production process. Journal of the Academy of Marketing Science, 36(1), 97-108. https://doi.org/10.1007/s11747-0070061-1

Fukuyama, F. (1995). Trust: The social virtues and the creation of prosperity (Vol. 99). New York: Free press New York. Retrieved from https://vanmierlostichting.d66.nl/content/uploads/sites/296/2016/02/Boekrecensie1.pdf

Fukuyama, F. (2000). Social capital and civil society.

Hikmat, H. (2001). Strategi pemberdayaan masyarakat. Bandung: Humaniora Utama Press.

Lambert, D. M., \& García-Dastugue, S. J. (2006). Cross-functional Business processes for the implementation. The Service-Dominant Logic of Marketing: Dialog, Debate, and Directions, 150.

Mees, H., Alexander, M., Gralepois, M., Matczak, P., \& Mees, H. (2018). Typologies of citizen co-production in flood risk governance. Environmental Science \& Policy, 89, 330339. https://doi.org/10.1016/j.envsci.2018.08.011

Miguel, E. A., Gertler, P., \& Levine, D. I. (2003). Did Industrialization Destroy Social Capital in Indonesia? CENTER FOR INTERNATIONAL AND DEVELOPMENTECONOMICS RESEARCH, (C03-131), 1-51. 
Mills, P. K., Chase, R. B., \& Margulies, N. (1983). Motivating the client/employee system as a service production strategy. Academy of Management Review, 8(2), 301-310.

Moelyono, M. (2007). Peran Modal Sosial dalam Memoderasi Pengaruh Jaringan Usaha dan Pembelajaran Organisasi Terhadap Kinerja UKM Sektor Manufaktur di Kota Palu. Universitas Negeri Malang.

Moelyono, M. (2010). Menggerakkan Ekonomi Kreatif Antara Tuntutan dan Kebutuhan. Jakarta: RajaGrafindo Persada.

Ostrom, E. (1996). Crossing the great divide: Coproduction, synergy, and development. World Development, 24(6), 1073-1087. https://doi.org/10.1016/0305-750X(96)00023-X

Polk, M. (2015). Transdisciplinary co-production: Designing and testing a transdisciplinary research framework for societal problem solving. Futures, 65, 110-122. https://doi.org/10.1016/j.futures.2014.11.001

Putnam, R. (1993). The prosperous community: Social capital and public life. The American Prospect, 13(Spring), Vol. 4. Available online: http://www. prospect. org/print/vol/13 (accessed 7 April 2003).

Putnam, R. D. (2011). Bowling Alone: America's Declining Social Capital. In The City Reader (pp. 166-174). Routledge.

Robison, L. J., Siles, M. E., \& Schmid, A. A. (2002). Social capital and poverty reduction: Toward a mature paradigm (p. 45) [Working or Discussion Paper]. Department ofAgricultural EconomicsMICHIGAN STATEUNIVERSITYEast Lansing, MI48824-1039. Retrieved from Department ofAgricultural EconomicsMICHIGAN STATEUNIVERSITYEast Lansing, MI48824-1039 website: https://ageconsearch.umn.edu/record/10941/

Tsai, W., \& Ghoshal, S. (1998). Social Capital and Value Creation: The Role of Intrafirm Networks. Academy of Management Journal, 41(4), 464-476. https://doi.org/10.5465/257085

Wiedmann, T. O., Lenzen, M., \& Barrett, J. R. (2009). Companies on the Scale. Journal of Industrial Ecology, 13(3), 361-383. https://doi.org/10.1111/j.15309290.2009.00125.x

World Bank. (1998). The Initiative on Defining, Monitoring and Measuring Social Capital: Overview and Program Description. Social Capital Initiative Working Paper No. 1. 